\title{
IMPLIKASI PERUBAHAN LINGKUNGAN BISNIS TERHADAP STRATEGI PERUSAHAAN, STUDI KASUS: PT BOGASARI FLOUR MILLS
}

\author{
Suwarsono Muhammad \\ Andi Yuliansyah \\ Fakultas Ekonomi Universitas Islam Indonesia \\ e-mail:suwarsono@fe.uii.ac.id
}

\begin{abstract}
This study discussed the emergence of business on PT Bogasari Flour mills before and after economic crisis 1997/1998 in Indonesia. Based on SWOT analysis with regard to business environment and governement policy, the study was able to identify prospected flour mills market. The results of the analysis indicate that government policy affected the implemented strategy of PT. Bogasari Flour Mills
\end{abstract}

Keyword: maklun, environmental, brand, strategy

\section{PENDAHULUAN}

Sebelum krisis ekonomi 1997/1998, di Indonesia, hampir seluruh sektor ekonomi yang 'basah' bersimpul pada kekuasaan. Fasilitas ekonomi yang paling mudah diingat antara lain proyek mobil nasional dan tata niaga cengkeh yang dilaksanakan oleh Badan Penyangga dan Pemasaran Cengkeh (BPPC) (Media Indonesia Online, 2007). Fasilitas-fasiltas ekonomi ini juga dinikmati Bogasari Flour Mills sebagai perusahaan yang bekerja sama dengan Bulog. Diresmikan oleh Presiden Soeharto, pabrik Bogasari pertama yang terletak di Tanjung Priok, Jakarta, berdiri pada 29
November 1971. Setelah itu menyusul pabrik kedua yang berlokasi di Tanjung Perak, Surabaya, pada 10 Juli 1972. Selama lebih dari 20 tahun, perusahaan ini benarbenar menjadi "anak manis" pemerintah. Pasalnya, ia ditunjuk sebagai "tukang giling" terigu milik pemerintah yang ditangani oleh Bulog. Dari situ, Bogasari mendapat upah (fee) giling (Eksekutif, 2002). Dari upah menggiling biji gandum menjadi tepung terigu perusahaan ini selalu mengalami keuntungan seperti terlihat dalam Tabel 1 (Indocement Tunggal Perkasa, 1995; Indofood Sukses Makmur, 1998).

Tabel 1: Laba Usaha dan Penjualan Bogasari 1992-1997

\begin{tabular}{llrlr}
\hline Tahun & & \multicolumn{1}{l}{ Penjualan } & & \multicolumn{1}{l}{ Laba Usaha } \\
\hline $1992^{1}$ & $\mathrm{Rp}$ & 195.920 .089 .387 & $\mathrm{Rp}$ & 46.703 .016 .009 \\
1993 & $\mathrm{Rp}$ & 658.760 .576 .175 & $\mathrm{Rp}$ & 85.427 .076 .302 \\
1994 & $\mathrm{Rp}$ & 793.867 .588 .915 & $\mathrm{Rp}$ & 96.163 .340 .841 \\
$1995^{2}$ & $\mathrm{Rp}$ & 946.598 .399 .748 & $\mathrm{Rp}$ & 139.557 .078 .922 \\
1996 & $\mathrm{Rp}$ & 1.046 .624 .506 .314 & $\mathrm{Rp}$ & 166.451 .493 .767 \\
1997 & $\mathrm{Rp}$ & 1.106 .119 .443 .390 & $\mathrm{Rp}$ & 179.940 .475 .631 \\
\hline
\end{tabular}


1 Akuisisi usaha terhadap Bogasari oleh Indocement berlaku efektif pada tanggal 31 Juli 1992. Karena itu, di dalam laporan keuangan PT Indocement pada tahun 1992, kinerja unit usaha Bogasari hanya berdasarkan periode lima bulan saja. ${ }^{2}$ Akuisisi usaha terhadap Bogasari oleh Indofood Sukses Makmur berlaku efektif pada tanggal 1 Juli 1995. Penjualan dan Laba Usaha Bogasari pada tahun 1995 berdasarkan Laporan Keuangan Indocement tahun 1995.

Fasilitas yang dinikmati PT Bogasari Flour Mills mulai berubah, ketika Indonesia mengalami krisis ekonomi 1997/1998. Pasalnya, IMF (International Monetary Fund) sebagai lembaga yang memberikan bantuan keuangan kepada pemerintah Indonesia untuk mengatasi krisis ekonomi, mensyaratkan liberalisasi sektor perdagangan termasuk di dalamnya industri tepung terigu dan gandum yang dimonopoli oleh Bulog (Badan Urusan Logistik). Dalam Memorandum Of Economic And Financial Policies (MEFP) yang disepakati IMF dan pemerintah Indonesia pada bulan Oktober 1997, deregulasi tataniaga gandum dinyatakan pada pasal 41 sebagai berikut (Indonesia and IMF, 1997).

The government intends to phase out impor and marketing monopolies and price controls on agricultural commodities except for rice, sugar, and cloves over the next three years. As a first step, on November 3, 1997, wheat and wheat flour, soybeans and garlic were made freely imporable. In order to alleviate the burden of adjustment on the part of the affected parties, import tariffs will be applied to soybeans and dried garlic (20 percent) and wheat flour (10 percent) and will be reduced to 5 percent by 2003 . Price controls on cement will be eliminated effective November 3, 1997.

Dibukanya keran impor tepung terigu membuat persaingan di bisnis tepung terigu lebih ramai. PT Bogasari Flour Mills menghadapinya dengan mengubah visi-misi dan budaya perusahaannya. Dari segi bisnis, anak usaha PT Indofood Sukses Makmur ini memperbaiki sistem distribusinya dan membranding produknya (Swa, 2007). Perusahaan ini kemudian mengimpor langsung gandum dari mancanegara-tanpa lagi tergantung kepada Bulog. Penjualan terigu hasil produksi mereka juga tak lagi mengandalkan Bulog (Trust, 2008). Bogasari Flour Mills pun juga harus berkompetisi dengan para imporir tepung terigu dan perusahaan penggilingan lain, baik perusahaan penggilingan lama maupun baru.

Tabel 2: Laba Usaha dan Penjualan Bogasari 1998-2007

\begin{tabular}{clrlr}
\hline Tahun & & \multicolumn{1}{l}{ Penjualan } & \multicolumn{2}{c}{ Laba Usaha } \\
\hline 1998 & $\mathrm{Rp}$ & 1.405 .219 .745 .430 & $\mathrm{Rp}$ & 347.613 .215 .609 \\
1999 & $\mathrm{Rp}$ & 2.757 .272 .314 .367 & $\mathrm{Rp}$ & 659.324 .483 .514 \\
2000 & $\mathrm{Rp}$ & 3.390 .917 .611 .314 & $\mathrm{Rp}$ & 711.034 .747 .177 \\
2001 & $\mathrm{Rp}$ & 5.309 .427 .511 .425 & $\mathrm{Rp}$ & 443.393 .697 .784 \\
2002 & $\mathrm{Rp}$ & 5.927 .050 .582 .049 & $\mathrm{Rp}$ & 411.754 .597 .120 \\
2003 & $\mathrm{Rp}$ & 6.086 .330 .462 .318 & $\mathrm{Rp}$ & 462.903 .120 .000 \\
2004 & $\mathrm{Rp}$ & 7.578 .645 .000 .000 & $\mathrm{Rp}$ & 812.852 .000 .000 \\
2005 & $\mathrm{Rp}$ & 7.923 .398 .000 .000 & $\mathrm{Rp}$ & 740.031 .000 .000 \\
2006 & $\mathrm{Rp}$ & 8.997 .423 .000 .000 & $\mathrm{Rp}$ & 1.022 .715 .000 .000 \\
2007 & $\mathrm{Rp}$ & 11.613 .505 .000 .000 & $\mathrm{Rp}$ & 1.340 .928 .000 .000 \\
\hline
\end{tabular}


Dalam perjalanannya, tenyata kinerja perusahaan Bogasari Flour Mills tidak terpengaruh dengan perubahan tata niaga tepung terigu dan gandum yang dipicu LoI (Letter of Intent) ini (Gwie, 2006) ॥Walaupun pada tahun 2001 dan 2002 laba usaha sempat menurun namun Bogasari Flour Mills tidak pernah mengalami kerugian. Ini dapat dilihat dari laba usaha dan penjualan Bogasari pada Tabel 2 di atas (Indofood Sukses Makmur, 2008). Kemudian laba usaha perusahaan cenderung meningkat lagi pada periode 2003-2007. Bahkan saat ini, Bogasari Flour Mills adalah penguasa pasokan terigu di pasar domestik. Skala produksi perusahaan yang berdiri pada 37 tahun silam itu sudah mencapai 3,6 juta ton per tahun. Perusahaan itu menguasai sekitar $70 \%$ pasokan terigu nasional. Seiring dengan itu, konsumsi terigu di dalam negeri juga terus membengkak. Berdasarkan data di Asosiasi Produsen Terigu Indonesia (Aptindo), sebanyak empat juta ton tepung terigu habis dikonsumsi di negeri ini pada 2006 lalu. Itu artinya, ada kenaikan konsumsi sebanyak 12\% dari tahun 2005. Tahun ini, kebutuhan itu diperkirakan akan naik lagi sekitar 5\% (Trust, 2008).

Hal yang menarik untuk dikaji sesuai dengan pembahasan di atas adalah adanya perubahan lingkungan bisnis yang akhirnya berujung pada deregulasi tataniaga impor gandum dan tepung terigu ternyata tidak menurunkan kinerja perusahaan Bogasari Flour Mills. Sebagai perusahaan yang selama ini hanya merupakan "maklun" menerima order dari pemerintah melalui Bulog sebagai penggiling gandum menjadi

\footnotetext{
1 Nama resmi sebenarnya Memorandum of Economic and Financial Policies (MEFP). Tapi kemudian disebut Letter of Intent dikarenakan merupakan surat yang ditujukan kepada IMF dari pemerintah Indonesia (diwakili Menteri Koordinator Ekonomi, Keuangan dan Industri, Menteri Keuangan, serta Gubernur Bank Indonesia) yang berisikan tentang kebijakan yang akan ditempuh pemerintah Indonesia dalam rangka penyehatan ekonomi.
}

tepung terigu menjadi perusahaan yang harus berkompetisi sesuai dengan mekanisme pasar. Bahkan pasca krisis ekonomi 1997/1998, Bogasari Flour Mills mampu bertahan menjadi perusahaan yang menguasai pangsa pasar tepung terigu domestik.

\section{KAJIAN TEORI}

Perusahaan didirikan dengan berbagai tujuan pokok, seperti memperoleh laba, meningkatkan harga saham, meninggikan volume penjualan, dan mempertahankan keberlangsungan hidupnya. Untuk mencapai tujuan perusahaan yang telah ditetapkan, manajemen perlu memperhatikan dua faktor pokok, yakni lingkungan eksternal yang tidak terkontrol oleh perusahaan dan faktor internal yang sepenuhnya berada dalam kendali perusahaan. Faktor eksternal merupakan lingkungan bisnis yang melingkupi operasi perusahaan yang daripadanya muncul peluang (opportunities) dan ancaman (threats) bisnis (Muhammad, 2004).

Sebagai lingkungan yang melingkupi operasi perusahaan dimana perusahaan itu berada, maka analisa lingkungan bisnis mutlak diperlukan dalam proses pembuatan strategi perusahaan. Sebuah perusahaan tidak beroperasi dalam sebuah isolasi, perusahaan bertindak dan bereaksi terhadap lingkungan yang sangat kompleks dimana lingkungan ini selalu berubah dan bergerak secara konstan (Bibeault, 1999). Sebuah strategi yang baik adalah strategi yang well-matched dengan situasi internal dan external perusahaan, dimana jika situasi perusahaan berubah secara signifikan, maka penyesuaian strategi perusahaan perlu dilakukan. Beberapa perubahan lingkungan internal dan eksternal perusahaan membutuhkan respon yang kecil atau bahkan tidak sama sekali, sedangkan beberapa perubahan lingkungan membutuhkan perubahan strategi secara signifikan. Bahkan dalam beberapa kejadian, perubahan lingkungan menyebabkan kesulitan yang besar dalam strategi (Thompson and Strickland, 2003). 
Dalam melakukan analisa lingkungan bisnis perlu dibedakan lingkungan bisnis negara maju dan lingkungan bisnis negara berkembang. Suwarsono Muhammad dalam bukunya Manajemen Strategik menyatakan bahwa lingkungan bisnis di negara berkembang memiliki karakteristik yang khas. Berbeda secara signifikan dengan yang dijumpai di negara maju. Lingkungan bisnis di banyak negara sedang berkembang lebih sering berubah dan perubahannya seringkali secara mendadak. Dengan demikian, memiliki kecenderungan yang tak menentu. Pemerintah, biasanya, masih banyak melakukan intervensi. Pengambilan keputusan ekonomis dan politis tampak tidak transparan. Oleh karena itu, tingkat ketidakpastian usaha menjadi lebih besar. Akibatnya, dapat dikatakan bahwa lingkungan bisnis di negara sedang berkembang memiliki pengaruh yang jauh lebih besar dalam menentukan kegagalan atau keberhasilan manajemen dibanding di negara maju. Berbeda dengan situasi di negara maju yang justru menunjuk pada pentingnya faktor internal (Muhammad, 2004). Pentingnya memahami perbedaan lingkungan bisnis di negara sedang berkembang dan negara maju disebutkan oleh James E. Austin dalam bukunya Managing in Developing Countries yang menyatakan (Austin, 1990).

Distinctive business environment derive directly from differences in development levels and processes between the less developed countries (LDCs) and the more developed nations. Those differences significantly affect all functional areas of management as well as overall strategies.

Many of the firms mentioned so far were able deal effectively with the problems they encountered and to reap corresponding financial rewards; others were not and suffered the economic consequences. A distinguishing feature of more successful companies in developing countries is their superior ability to understand and interact with their business environment. A key to formulating effective business strategies in LDCs id the capacity to analyze and comprehend the firm's external environment. Management's challenge is to devise systematic approach to environmental analysis that enables effective managerial response.

Lebih lanjut Austin (1990) memberikan pandangan konseptual tentang Environmental Analysis Framework (EAF) bagi para manajer untuk menganalisa, memahami, dan mengatur kekuatan eksternal yang melingkupi perusahaan. Para manajer berhadapan dengan dua pertanyaan yang mendasar yaitu, apa yang dianalisa dalam lingkungan bisnis, dan bagaimana menilai relevansinya dengan strategi perusahaan. Menurut Austin (1990), langkah pertama adalah memilah kekuatan eksternal menjadi empat kategori faktor lingkungan yaitu: ekonomi (economic), politik (political) kebudayaan (cultural), dan demografi (demographic). Langkah kedua adalah memberikan gambaran lingkungan bisnis mempunyai empat level yaitu: international level yang terdiri dari beberapa hal tentang interaksi antar negara, national level yang terbentuk oleh strategi dan kebijakan pemerintah, industry level yang melibatkan lingkungan kompetitif perusahaan, dan company level yang terdiri dari strategi dan operasi perusahaan.

Level lingkungan diatas kemudian digambarkan bergerak dari level yang paling makro atau jarak terjauh dari perusahaan ke arah yang paling mikro di level internal perusahaan itu sendiri. Setiap level pada keempat level-international, national, industry, dan company- dibentuk oleh seluruh faktor lingkungan: economic, political, cultural, dan demographic. Menurut Austin (1990) aksi pada setiap level dapat mempengaruhi ketiga level lainnya dimana semuanya bersifat interaktif. Gambar 1 menampilkan ringkasan pandangan tentang Environmental Analysis Framework (EAF). 


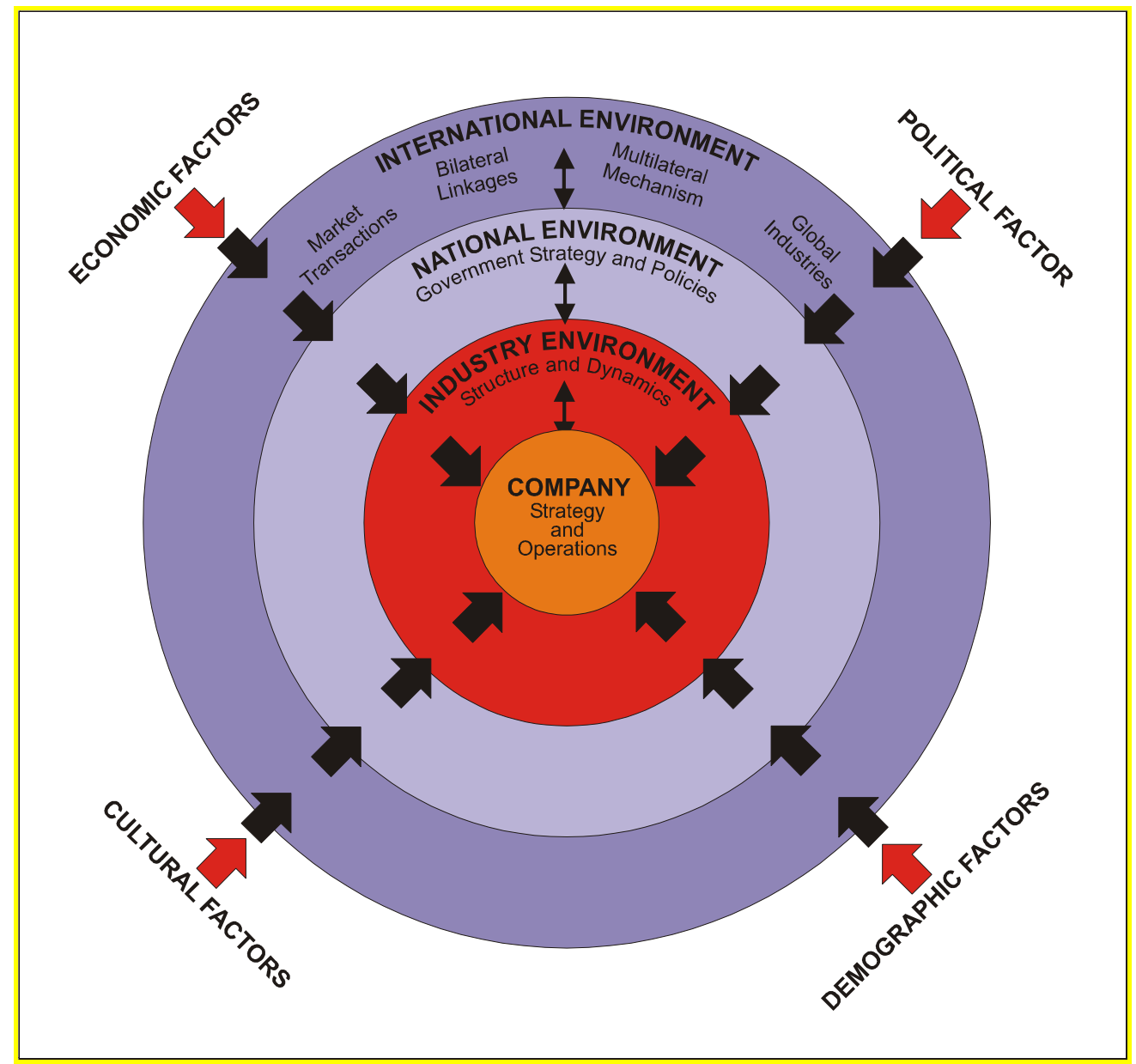

Gambar 1: Environmental Analysis Framework

Lingkungan Bisnis Tepung Terigu dan Gandum Pra Krisis Ekonomi 1997/1998, serta Strategi Bogasari Flour Mills

Sejarah industri tepung terigu Indonesia diawali pada awal tahun 1970an berangkat dari pemikiran perlunya diversifikasi pangan akibat ketergantungan terhadap beras. Pemicunya adalah pengalaman pahit kekurangan beras tahun 1968 dan 1972. Kemudian untuk menghindari ketergantungan beras yang harganya tidak stabil dan stoknya terbatas maka pemerintah intensif memperkenalkan terigu. Per- timbangannya adalah harga gandum relatif stabil dan volume yang diperdagangkan cukup banyak serta beras dapat bersubsidi dengan terigu. Amerika Serikat sangat berperan dalam kebijakan ini dengan memberikan bantuan dan hutang lunak untuk impor gandum (Ariani, 2008). Bantuan pangan ini dikenal dengan sebutan PL-480 (Public Law 480). Ada juga bantuan gandum dari negara-negara Eropa Barat. Untuk mengatasi krisis pangan inilah maka pemerintah menugaskan Bulog untuk menanganinya (Kompas, 1992). Sebelum 
didirikannya PT Prima di Makasar (1970) dan PT Bogasari Flour Mills (1971), gandum yang kita terima diolah dulu di Singapura untuk dijadikan tepung terigu. Namun kemudian hal ini dirasa terlalu mahal. Lalu Indonesia membangun sendiri pabrik tepung terigu bersamaan dengan meningkatnya permintaan masyarakat akan bahan makanan ini (Kompas, 1992). Selain itu lama-kelamaan disadari bahwa terigu yang tiba di pelabuhan Indonesia sering mengalami penurunan kualitas, seperti berkutu atau bau "apek" akibat waktu yang cukup lama selama perjalanan. Kondisi dan kandungan gizi tepung terigu tersebut menjadi tidak optimal lagi dibandingkan jika terigu tersebut dapat diproduksi sendiri di Indonesia (Bogasariflour, 2008a).

Namun, selama lebih dari 20 tahun industri tepung terigu merupakan industri yang tertutup yang tidak bisa dimasuki oleh investor lain. Dengan Keputusan Presiden (Keppres) industri tepung terigu dimasukkan kedalam bidang usaha yang tertutup untuk penanaman modal, kecuali untuk proyek baru yang sekurang-kurang-kurang $65 \%$ produksinya dieksport atau perluasan. Penutupan ini berlaku bagi Penanaman Modal Dalam Negeri (PMDN), Penanaman Modal Asing (PMA), maupun jenis usaha non PMDN atau PMA (Keppres, 1991 dan 1992). Akibatnya selama itu hanya ada dua perusahaan penggilingan tepung terigu yaitu, PT Bogasari Flour Mills dan PT Berdikari Sari Utama, sebelumnya PT Prima (Robinson, 1986; Indocommercial, 1997). Baru pada tahun 1993 dengan dikeluarkannya Keppres No. 54/1993 tanggal 10 Juni 1993 tentang Daftar Negatif Investasi (DNI) industri tepung terigu dinyatakan sebagai dicabut dari daftar industri yang tertutup. Akan tetapi, keinginan membangun pabrik terigu baru itu tampaknya sulit diwujudkan (Kompas, 1998). Kondisi ini dikarenakan impor biji gandum yang merupakan bahan baku pembuatan tepung terigu masih merupakan monopoli Bulog (Pusat Data Business Indonesia, 1994). Kewenangan Bulog untuk melakukan impor biji gandum dinyatakan dalam Keputusan Menteri Perdagangan Republik Indonesia (1995) Dengan adanya peraturan ini berarti pendirian pabrik tepung terigu baru akan sangat tergantung pada kebijakan distribusi gandum dari Bulog sebagai pemegang ijin tunggal impor biji gandum.

Sedangkan permintaan akan tepung terigu dari tahun ke tahun naik seiring dengan naiknya tingkat konsumsi produk gandum (Tabel 3). Naiknya tingkat konsumsi gandum dan produk olahannya salah satunya dikarenakan faktor demografi. Pertumbuhan penduduk Indonesia yang mencapai 96,6 juta di tahun 1961 meningkat lebih dari dua kali lipat, mencapai 195,5 juta pada tahun 1996, serta urbanisasi yang hanya $14,8 \%$ di tahun 1961 sudah mencapai $35,9 \%$ di tahun 1996. Daya tarik perkotaan menawarkan berbagai kelebihan dalam bentuk produktivitas dan pendapatan yang lebih tinggi serta menarik investasi baru, teknologi baru, pekerja terdidik dan terampil dalam jumlah yang jauh lebih tinggi dibanding pedesaan. Urbanisasi yang tinggi ini menyebabkan masyarakat menginginkan makanan yang lebih praktis. Faktor inilah yang menyebabkan produk olahan gandum seperti (mie, roti, dan kue) mengalami peningkatan.

\footnotetext{
2 Keputusan ini mengatur tentang barang-barang tertentu yang hanya bisa diimpor oleh perusahaan imporir maupun lembaga negara tertentu. Termasuk dalamnya adalah Bulog sebagai lembaga yang diberi tugas pokok untuk menjaga stabilitas harga beberapa bahan pokok termasuk gandum.
} 
Tabel 3: Perkembangan Tingkat Konsumsi Perkapita Produk Gandum per minggu Tahun 1980-1996

\begin{tabular}{lcccccccc}
\hline \multicolumn{1}{c}{ Daerah/makanan } & Satuan & $\mathbf{1 9 8 0}$ & $\mathbf{1 9 8 4}$ & $\mathbf{1 9 8 7}$ & $\mathbf{1 9 9 0}$ & $\mathbf{1 9 9 3}$ & $\mathbf{1 9 9 6}$ \\
\hline Terigu - Wheat flour & $\mathrm{Kg}$ & 0,028 & 0,19 & 0,018 & 0,017 & 0,021 & 0,02 \\
Mi instan - Instant noodle & $80 \mathrm{gr}$ & - & - & - & - & - & 0,601 \\
Mie/ Mie basah - Wheat noodle/s & $\mathrm{Kg}$ & 0,115 & 0,011 & 0,013 & 0,018 & 0,031 & 0,005 \\
Mi bakso/rebus/goreng - Noodle & (with & $\mathrm{Porsi}$ & - & - & - & - & - & 0,548 \\
meatballs/boiled/fried) & Porsi & - & - & - & - & - & 0,032 \\
Mi instan - Instant noodle & $0,1 \mathrm{Kg}$ & - & - & 0,115 & 0,133 & 0,176 & - \\
Roti tawar - Ordinary bread & Bks Kecil & - & - & - & - & - & 0,119 \\
Roti tawar - Ordinary bread & Potong & - & - & - & - & - & 0,355 \\
Roti manis - Other bread & & & & & & & \\
& $\mathrm{Kg}$ & 0,018 & 0,011 & 0,01 & 0,011 & 0,011 & 0,015 \\
Terigu - Wheat flour & $80 \mathrm{gr}$ & - & - & - & - & - & 0,272 \\
Mi instan - Instant noodle & $\mathrm{Kg}$ & 0,075 & 0,008 & 0,007 & 0,101 & 0,014 & 0,003 \\
Mie/ Mie basah - Wheat noodle/s & & & & & & & \\
Mi bakso/rebus/goreng - Noodle (with & Porsi & - & - & - & - & - & 0,262 \\
meatballs/boiled/fried) & Porsi & - & - & - & - & - & 0,016 \\
Mi instan - Instant noodle & $0,1 \mathrm{Kg}$ & - & - & 0,019 & 0,016 & 0,026 & - \\
Roti tawar - Ordinary bread & Bks Kecil & - & - & - & - & - & 0,037 \\
Roti tawar - Ordinary bread & Potong & - & - & - & - & - & 0,29 \\
Roti manis - Other bread & dari Survey Sosial Ekonomi Sosial (Susenas)
\end{tabular}

Sumber: Badan Pusat Statistik, diolah dari Survey Sosial Ekonomi Sosial (Susenas) tahun 1980, 1984, 1987, 1990, 1993, 1996.

Dalam lingkungan bisnis tepung terigu dan gandum pra krisis ekonomi 1997/1998. Bogasari Flour Mills menerapkan strategi fungsional produksi dan operasi. Strategi produksi dilakukan dengan meningkatkan kapasitas produksi seiring dengan kenaikan konsumsi tepung terigu nasional. Selain itu efisiensi juga dilakukan untuk meningkatkan keuntungan dari penjualan produk sampingan (by product) yang menjadi hak Bogasari Flour Mills (Bogasariflour, 2008b) Pilihan strategi ini tidak lepas

\footnotetext{
${ }^{3}$ Dari bahan baku yang diserahkan, maka Bogasari Flour Mills diharuskan menyerahkan hasil penggilingan berupa tepung terigu senilai $74 \%$ dari volume biji gandum yang diserahkan oleg Bulog. Sedangkan sisa volume biji gandum yang digiling, sesuai dengan peraturan pemerintah, dimiliki dan dijual langsung oleh Bogasari ke pasar lokal dan eksport pada harga pasar. Produk sampingan (by product) ini berupa "bran",
}

dari supply dan demand yang dimonopoli oleh Bulog sebagai konsekuensi kebijakan pemerintah. Sedangkan strategi operasi dilakukan dengan mendirikan divisi-divisi yang mendukung kelancaran proses produksi (Bogasariflour, 2008b).

\footnotetext{
"pollard" untuk industri makanan ternak, dan tepung industri untuk industri kayu lapis. Bisa dililah dalam Catatan Atas Laporan Keuangan Konsolidasi PT Indofood Sukses Makmur Tbk dan Anak Perusahaan, 31 Desember 1998 dan 1997, Bagian PerjanjianPerjanjian dan Komitmen-Komitmen.

${ }^{4}$ Bogasari Flour Mills mempunyai Divisi Kemasan yang didirikan pada tahun 1977 di Citeureup, Jawa Barat yang memproduksi kebutuhan kantong terigu untuk kedua pabrik tepung terigu, serta Divisi Maritim yang mengoperasikan tiga kapal angkut gandum dan tiga buah kapal tongkang untuk pelayaran antar pulau. Pada tahun 1995, kontribusi kapal-kapal dari divisi maritim ini mencapai $25 \%$ dari total jumlah pengiriman impor gandum oleh pemerintah.
} 
Dari dua lokasi pabrik Bogasari Flour Mills, peningkatan kapasitas produksi banyak dilakukan di Jakarta dengan cara peningkatan kapasitas giling dari mill yang sudah terpasang atau dengan penambahan mill baru. Pabrik Bogasari di Jakarta hanya bermula dari dua mill (mill $A$ dan mill B) dengan kapasitas produksi 650 ton/hari pada tahun 1971, yang kemudian ditingkatkan menjadi enam mill, dengan total kapasitas produksi 3.500 ton/hari pada tahun 1984, seperti yang terlihat pada Tabel 4 (Indocommercial, 1997).

Tabel 4: Pertumbuhan Kapasitas Produksi PT Bogasari Flour Mills Periode Tahun 19711984

\begin{tabular}{|c|c|c|c|c|c|}
\hline Tahun & Lokasi Penggilingan & Mill & $\begin{array}{c}\text { Produksi/Hari } \\
\text { (ton) }\end{array}$ & $\begin{array}{l}\text { Produksi/Tahun* } \\
\text { (ton) }\end{array}$ & $\begin{array}{c}\text { Per- } \\
\text { tumbuhan } \\
(\%) \\
\end{array}$ \\
\hline \multirow{2}{*}{1971} & Bogasari Flour Mills (Jkt) & Mill A \& Mill B & 650 & 236.600 & \\
\hline & Total Kapasitas Produksi & & 650 & 236.600 & \\
\hline \multirow{3}{*}{1972} & Bogasari Flour Mills (Jkt) & Mill A \& Mill B & 650 & 236.600 & \\
\hline & Bogasari Flour Mills (Sby) & Mill A \& Mill B & 650 & 236.600 & \\
\hline & Total Kapasitas Produksi & & 1.300 & 405.600 & $71,4 \%$ \\
\hline \multirow{4}{*}{1978} & Bogasari Flour Mills (Jkt) & Mill A \& Mill B & 650 & 236.600 & \\
\hline & Bogasari Flour Mills (Jkt) & Mill C \& Mill D & 1.000 & 364.000 & \\
\hline & Bogasari Flour Mills (Sby) & Mill A \& Mill B & 650 & 236.600 & \\
\hline & Total Kapasitas Produksi & & 2.300 & 837.200 & $106,4 \%$ \\
\hline \multirow{4}{*}{1982} & Bogasari Flour Mills (Jkt) & Mill A \& Mill B & 800 & 291.200 & \\
\hline & Bogasari Flour Mills (Jkt) & Mill C \& Mill D & 1.000 & 364.000 & \\
\hline & Bogasari Flour Mills (Sby) & Mill A \& Mill B & 800 & 291.200 & \\
\hline & Total Kapasitas Produksi & & 2.600 & 946.400 & $13,0 \%$ \\
\hline \multirow{5}{*}{1984} & Bogasari Flour Mills (Jkt) & Mill A \& Mill B & 800 & 291.200 & \\
\hline & Bogasari Flour Mills (Jkt) & Mill C \& Mill D & 1.000 & 364.000 & \\
\hline & Bogasari Flour Mills (Jkt) & Mill E \& Mill F & 1.700 & 618.800 & \\
\hline & Bogasari Flour Mills (Sby) & Mill A \& Mill B & 800 & 291.200 & \\
\hline & Total Kapasitas Produksi & & 4.300 & 1.565 .200 & $65,4 \%$ \\
\hline
\end{tabular}

* Dihitung berdasarkan 7 hari produksi dengan periode satu tahun terdiri dari 52 minggu. 
Tabel 5: Pertumbuhan Kapasitas Produksi PT Bogasari Flour Mills Periode Tahun 1992-1997

\begin{tabular}{ccc}
\hline Tahun & $\begin{array}{c}\text { Kapasitas } \\
\text { Produksi* } \\
\text { (ton) }\end{array}$ & $\begin{array}{c}\text { Pertumbuhan } \\
(\%)\end{array}$ \\
\hline 1992 & 2.100 .000 & - \\
1993 & 2.100 .000 & $0,0 \%$ \\
1994 & 2.400 .000 & $14,3 \%$ \\
1995 & 2.400 .000 & $0,0 \%$ \\
1996 & 3.000 .000 & $25,0 \%$ \\
1997 & 3.600 .000 & $20,0 \%$ \\
\hline \multicolumn{2}{l}{ Rata-rata pertumbuhan } \\
pertahun
\end{tabular}

* Merupakan total kapasitas produksi pabrik Bogasari Flour Mills di Jakarta dan Surabaya dalam ton pertahun

Memasuki era 1990an peningkatan kapasitas produksi tepung terigu Bogasari Flour Mills juga terus dilakukan untuk mempertahankan pangsa pasar. Sejak diakuisi oleh PT Indocement Tunggal Perkasa pada tahun 1992, dan kemudian dibeli oleh PT Indofood Sukses Makmur pada tahun 1995, maka kapasitas produksi kedua pabrik Bogasari ditingkatkan dari 2.100 .000 ton/tahun menjadi 3.600.000 ton/tahun atau meningkat $71,4 \%$, seperti yang disajikan dalam Tabel 5 (Indocement Tunggal Perkasa, 1995; Indofood Sukses Makmur, 2008). Selama periode ini rata-rata pertumbuhan kapasitas produksi pertahun mencapai $11,9 \%$ per tahun. Secara keseluruhan program peningkatan kapasitas produksi sampai pada tahun 1997 diperkirakan menelan biaya investasi US\$230 juta (Indocement Tunggal Perkasa, 1995).

Efektifitas strategi bisnis Bogasari Flour Mills dalam mempertahankan pangsa pasar tepung terigu bisa dilihat dalam Tabel 6 (Indocommercial, 1997). Dari tahun 1992 sampai 1996, Bogasari menguasai pangsa pasar suplai tepung terigu nasional jauh diatas Berdikari Sari Utama maupun tepung terigu impor. Penurunan hanya terjadi pada tahun 1995 mencapai $83,9 \%$ dari tahun sebelumnya 89,6\%. Namun pada tahun 1996 pangsa pasar Bogasari melonjak lagi menjadi $91,8 \%$. Dalam periode ini rata-rata penguasaan pasar PT Bogasari Flour Mills dalam pasar tepung terigu nasional mencapai $87,9 \%$ seperti yang terlihat pada Gambar 2 (Indocommercial, 1997).

Tabel 6: Pangsa Pasar Tepung Terigu NasionalPeriode Tahun 1992-1996

\begin{tabular}{ccccccccc}
\hline \multirow{2}{*}{ Tahun } & \multicolumn{2}{c}{$\begin{array}{c}\text { PT Bogasari Flour } \\
\text { Mills }\end{array}$} & \multicolumn{2}{c}{$\begin{array}{c}\text { PT Berdikari Sari } \\
\text { Utama }\end{array}$} & \multicolumn{2}{c}{ Import - Eksport } & \multicolumn{2}{c}{$\begin{array}{c}\text { Total Suplai } \\
\text { Nasional }\end{array}$} \\
\cline { 2 - 10 } & Ton & $\mathbf{( \% )}$ & Ton & $\mathbf{( \% )}$ & Ton & $\mathbf{( \% )}$ & Ton & $(\boldsymbol{\%})$ \\
\hline 1992 & 1.647 .450 & $86,8 \%$ & 211.736 & $11,2 \%$ & 38.874 & $2,0 \%$ & 1.898 .060 & $100,0 \%$ \\
1993 & 1.822 .138 & $87,6 \%$ & 216.990 & $10,4 \%$ & 41.569 & $2,0 \%$ & 2.080 .697 & $100,0 \%$ \\
1994 & 2.170 .812 & $89,6 \%$ & 227.983 & $9,4 \%$ & 24.948 & $1,0 \%$ & 2.423 .743 & $100,0 \%$ \\
1995 & 2.335 .830 & $83,9 \%$ & 289.294 & $10,4 \%$ & 157.897 & $5,7 \%$ & 2.783 .021 & $100,0 \%$ \\
1996 & 2.571 .292 & $91,8 \%$ & 208.802 & $7,5 \%$ & 20.207 & $0,7 \%$ & 2.800 .301 & $100,0 \%$ \\
\hline Rata-rata & $\mathbf{2 . 1 0 9 . 5 0 4}$ & $\mathbf{8 7 , 9 \%}$ & $\mathbf{2 3 0 . 9 6 1}$ & $\mathbf{9 , 8 \%}$ & $\mathbf{5 6 . 6 9 9}$ & $\mathbf{2 , 3 \%}$ & $\mathbf{2 . 3 9 7 . 1 6 4}$ & $\mathbf{1 0 0 , 0 \%}$ \\
\hline
\end{tabular}




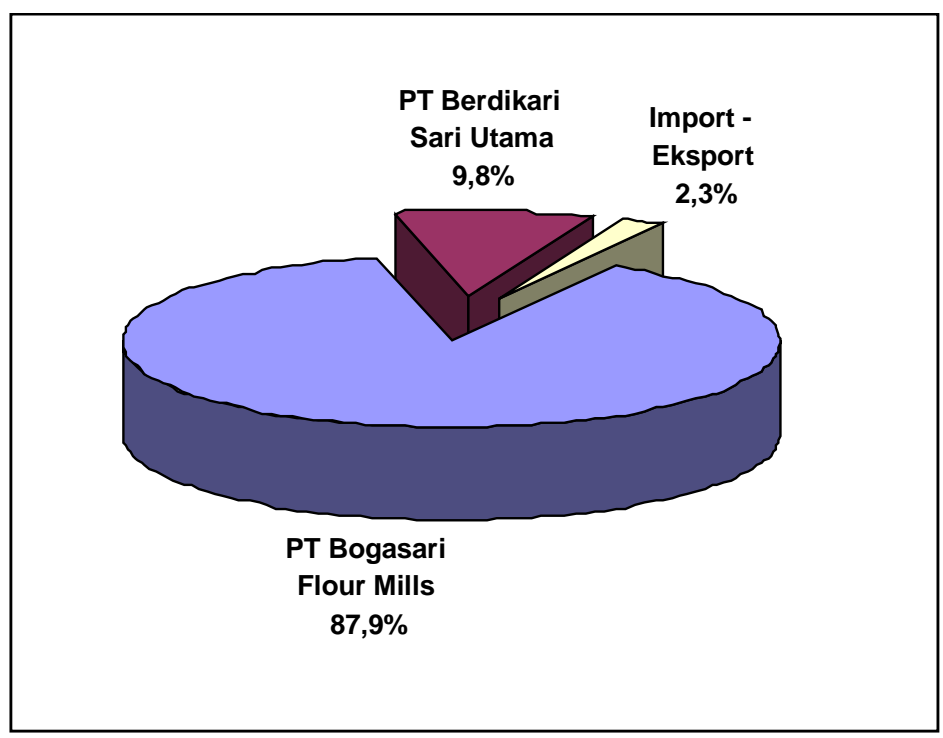

Gambar 2: Rata-Rata Market Share Tepung Terigu Nasional Periode Tahun 1992-1996

\section{Lingkungan Bisnis Tepung Terigu dan Gandum Pasca Krisis Ekonomi 1997/1998, serta Strategi Bogasari Flour Mills}

Pasca krisis ekonomi 1997/1998, tata niaga tepung tepung terigu dan gandum berubah total. Bulog tidak lagi memiliki wewenang dalam memonopoli impor gandum maupun tepung terigu. Praktis peran pemerintah dalam tata niaga gandum dan terigu pasca krisis ekonomi 1998 adalah sebatas pada penentuan tarif bea masuk gandum dan tepung terigu. Beberapa perusahaan penggilingan terigu juga mulai meramaikan industri ini, seperti yang terlihat pada Tabel 7 (Indocommercial, 2005; Kontan Online, 2006). Tetapi dari kedelapan produsen tepung terigu yang sudah berproduksi maupun dalam rencana, Bogasari Flour Mills masih merupakan produsen terbesar di Indonesia Selain itu, dengan

\footnotetext{
5 Dari Annual Report Indofood dan Indocement dikatakan kapasitas produksi pabrik penggilingan PT Bogasari Mills di Jakarta dan Surabaya pada tahun 1997 sudah mencapai 3,6 juta ton/tahun. Sedangkan
}

dibukanya keran impor tepung terigu, maka produsen dalam negeri juga harus bersaing dengan terigu impor yang bebas diimpor oleh imporir umum. Ledakan impor terigu langsung terasa pada tahun 1999 yang mencapai 366.945 ton, padahal pada tahun 1998 hanya 22.674 ton, seperti yang dapat dilihat pada Grafik 1. Ini berarti naik 344.271 ton atau naik 15 kali lipat lebih. Selanjutnya impor terigu naik lagi pada tahun 2000 mencapai 459.064 ton. Membanjirnya tepung terigu impor dari beberapa negara ini selain adanya kebebasan dalam mengimpor tepung juga adanya kebijakan dumping dari produsen tepung terigu luar negeri seperti China, Uni Emirat Arab, Australia, Uni Eropa dan India (Sinar Harapan, 2002). Akibatnya, harga tepung terigu impor menjadi murah jika dibandingkan tepung terigu produksi produsen dalam negeri.

\footnotetext{
dari sumber Indocommercial, CAPRICORN Indonesia Consult Inc. kapasitas produksi pabrik penggilingan PT Bogasari Mills di Jakarta dan Surabaya pada tahun 1997 sudah mencapai 3,9 juta ton/tahun.
} 
Tabel 7: Produsen Tepung Terigu Indonesia

\begin{tabular}{llclcc}
\hline No & \multicolumn{1}{c}{ Nama Perusahaan } & $\begin{array}{c}\text { Tahun } \\
\text { Berdiri }\end{array}$ & Lokasi & $\begin{array}{c}\text { Kapasitas Produksi } \\
\text { (ton/tahun) }\end{array}$ & Keterangan \\
\hline 1 & PT Bogasari Flour Mills & 1971 & Jakarta \& Sby & 3.972 .000 & Produksi \\
2 & PT Eastern Flour Mills & 1982 & Ujung Pandang & 1.110 .000 & Produksi \\
3 & PT Panganmas Inti Persada & 1994 & Cilacap & 300.000 & Produksi \\
4 & PT Sriboga Raturaya & 1997 & Semarang & 450.000 & Produksi \\
5 & PT Asia Raya & 2005 & Sidoarjo & 72.000 & Rencana \\
6 & PT Purnomo Sejati & 2005 & Sidoarjo & 120.000 & Rencana \\
7 & PT Fugui Flour \& Grain Indonesia & 2005 & Gresik & 270.000 & Produksi \\
8 & PT Kwala Intan New Grain & 2005 & Asahan & 210.000 & Rencana \\
\hline & Total Produksi & & $\mathbf{6 . 5 0 4 . 0 0 0}$ & \\
\hline
\end{tabular}

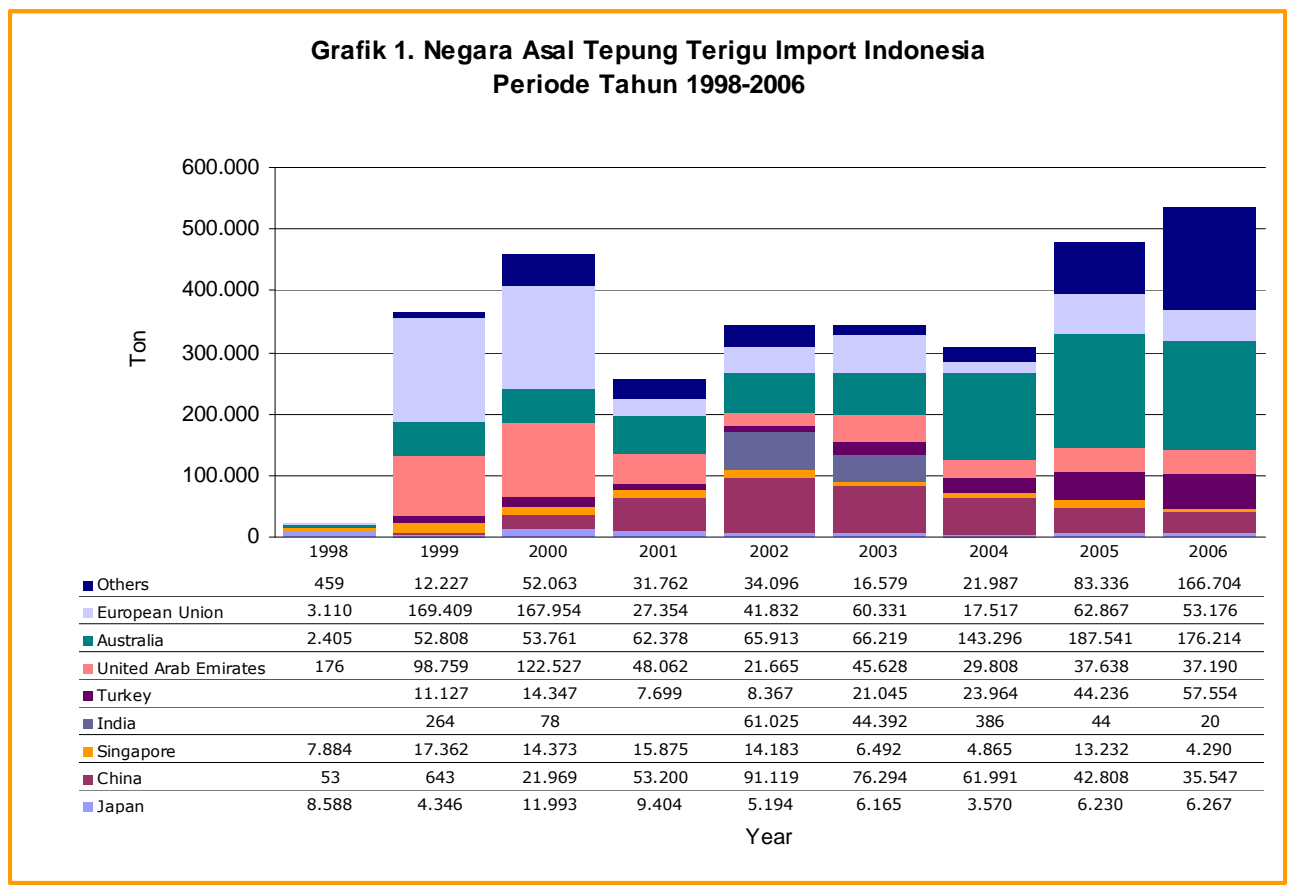

Sumber: Dikutip dan diolah dari Eksport-Impor, Badan Pusat Statistik. tahun 1998-2007. Impor terigu disini hanya meliputi Wheat or Meslin Flour (SITC Code: 04610000, HS Code: 110100000). 
Sedangkan dari sisi permintaan, konsumen terbesar tepung terigu adalah pengguna lainnya, yang dimaksud dengan pengguna lainnya adalah penjaja makanan jalanan yang terbuat dari tepung terigu, seperti mie basah dan makanan gorengan, yang terkenal dengan sebutan street vendor dan termasuk dalam Usaha Kecil Menengah (UKM) (Indocommercial, 2001). Sebenarnya sejak sebelum krisis ekonomi pengguna tepung terigu pada usaha street vendor merupakan konsumen terbesar tepung terigu. Seperti data yang terlihat di Tabel 8, pada tahun 1996, jenis usaha ini sudah menyerap 1,5 juta ton dari total konsumsi
3,4 juta ton, (Indocommercial, 2001). Penyerapan tepung terigu pada jenis usaha ini agak sedikit turun ketika krisis ekonomi pada tahun 1997-1998. Juga pada saat deregulasi tata niaga tepung terigu yang berlaku efektif tahun 1999 dimana harga tepung terigu menjadi mahal. Namun Tabel 9 menunjukkan rata-rata penyerapan tepung terigu pada jenis usaha ini masih terbesar mencapai $40 \%$ pada periode 1996-2000 (Indocommercial, 2001). Sedangkan ratarata persentase penggunaan tepung terigu untuk produk seperti mie instant dan roti pada periode yang sama mencapai $20,8 \%$ dan $20,0 \%$.

Tabel 8: Konsumsi Tepung Terigu Berdasarkan PenggunanyaPeriode Tahun 1996-2000

\begin{tabular}{|c|c|c|c|c|c|c|c|c|c|}
\hline \multirow[b]{2}{*}{ Tahun } & \multirow{2}{*}{$\begin{array}{c}\text { Rumah } \\
\text { Tangga } \\
\\
(\text { ton }) \\
\end{array}$} & \multicolumn{6}{|c|}{ Industri } & \multirow[b]{2}{*}{$\begin{array}{l}\text { Total } \\
\text { (ton) } \\
\end{array}$} & \multirow{2}{*}{$\begin{array}{c}\text { Pertumbuha/ } \\
\text { Penurunan } \\
(\%) \\
\end{array}$} \\
\hline & & $\begin{array}{c}\text { Mie } \\
\text { Instant } \\
\text { (ton) }\end{array}$ & $\begin{array}{l}\text { Roti } \\
\text { (ton) }\end{array}$ & $\begin{array}{c}\text { Biskuit } \\
(\text { ton })\end{array}$ & $\begin{array}{c}\text { Snack } \\
(\text { ton })\end{array}$ & $\begin{array}{c}\text { Plywood } \\
\text { (ton) }\end{array}$ & $\begin{array}{c}\text { Lainnya } \\
\text { (ton) }\end{array}$ & & \\
\hline 1996 & 549.248 & 694.853 & 613.536 & 91.619 & 13.168 & 7.991 & 1.500 .861 & 3.471 .276 & \\
\hline 1997 & 517.145 & 697.266 & 716.344 & 95.396 & 14.273 & 7.509 & 1.285 .633 & 3.333 .566 & $-3,97 \%$ \\
\hline 1998 & 446.047 & 592.676 & 590.511 & 80.604 & 14.987 & 7.291 & 1.193 .743 & 2.925 .859 & $-12,23 \%$ \\
\hline 1999 & 469.241 & 621.700 & 600.902 & 83.015 & 12.160 & 5.897 & 861.290 & 2.654 .205 & $-9,28 \%$ \\
\hline 2000 & 522.266 & 675.487 & 630.065 & 88.906 & 12.714 & 5.577 & 1.571 .255 & 3.506 .270 & $32,10 \%$ \\
\hline 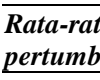 & & & & & & & & & $1,66 \%$ \\
\hline
\end{tabular}

Tabel 9: Persentase Konsumsi Tepung Terigu Berdasarkan Penggunanya Periode Tahun 1996-2000

\begin{tabular}{ccccccccc}
\hline \multirow{2}{*}{ Tahun } & \multirow{2}{*}{ Rumah Tangga } & \multicolumn{9}{c}{ Industri } \\
& & Mie Instant & Roti & Biskuit & Snack & Plywood & Lainnya & Total \\
& $(\%)$ & $(\%)$ & $(\%)$ & $(\%)$ & $(\%)$ & $(\%)$ & $(\%)$ & $(\%)$ \\
\hline 1996 & $15,8 \%$ & $20,0 \%$ & $17,7 \%$ & $2,6 \%$ & $0,4 \%$ & $0,2 \%$ & $43,2 \%$ & $100,0 \%$ \\
1997 & $15,5 \%$ & $20,9 \%$ & $21,5 \%$ & $2,9 \%$ & $0,4 \%$ & $0,2 \%$ & $38,6 \%$ & $100,0 \%$ \\
1998 & $15,2 \%$ & $20,3 \%$ & $20,2 \%$ & $2,8 \%$ & $0,5 \%$ & $0,2 \%$ & $40,8 \%$ & $100,0 \%$ \\
1999 & $17,7 \%$ & $23,4 \%$ & $22,6 \%$ & $3,1 \%$ & $0,5 \%$ & $0,2 \%$ & $32,5 \%$ & $100,0 \%$ \\
2000 & $14,9 \%$ & $19,3 \%$ & $18,0 \%$ & $2,5 \%$ & $0,4 \%$ & $0,2 \%$ & $44,8 \%$ & $100,0 \%$ \\
Rata-rata & $\mathbf{1 5 , 8 \%}$ & $\mathbf{2 0 , 8 \%}$ & $\mathbf{2 0 , 0 \%}$ & $\mathbf{2 , 8 \%}$ & $\mathbf{0 , 4 \%}$ & $\mathbf{0 , 2 \%}$ & $\mathbf{4 0 , 0 \%}$ & $\mathbf{1 0 0 , 0 \%}$ \\
\hline
\end{tabular}


Untuk mengatasi persaingan dengan tepung terigu impor dan produsen tepung terigu yang bermunculan, Bogasari Flour Mills menerapkan strategi diferensiasi. Memiliki kelemahan tidak bisa bersaing dengan tepung terigu impor dalam masalah harga jual, maka pilihan strategi diferensiasi adalah strategi bersaing yang ideal bagi Bogasari Flour Mills. Karena dengan produk yang terdiferen (berbeda) dibandingkan dengan produk pesaingnya, maka harga yang lebih tinggi tidak akan menjadi masalah bagi pelanggan tepung terigu. Pelanggan tepung terigu akan merasa adanya perbedaan harga produk Bogasari Flour Mills dibandingkan dengan produk pesaing lainnya dikarenakan adanya perbedaan kualitas produk. Singkatnya, harga produk Bogasari Flour Mills lebih mahal karena kualitas produknya lebih baik dibandingkan produk pesaingnya.

Sebelum krisis ekonomi, produk Bogasari Flour Mills yang dijual oleh Bulog di pasaran adalah produk generik dengan tiga merek yaitu: Cakra Kembar, Segitiga Biru dan Kunci Biru. Ketiga merek inipun hanya untuk membedakan kandungan protein yang terdapat dalam tepung terigu (Swasembada, 2000). Cakra Kembar untuk tepung terigu dengan kandungan protein tinggi, Segitiga Biru untuk tepung terigu dengan kandungan protein sedang, dan Kunci Biru untuk tepung terigu dengan kandungan protein rendah. Ketiga produk ini dikemas dengan ukuran sak $(25 \mathrm{~kg})$, tidak ada kemasan praktis misalnya $1 \mathrm{~kg}$. Sehingga pembelian di bawah $25 \mathrm{~kg}$ harus dipecah dengan bungkus lain (misalnya plastik bening tanpa merek). Akibatnya konsumen tidak begitu peduli dengan masalah merek (brand name). Perpindahan merek (brand switching) cukup tinggi khususnya pada segmen UKM dan rumah tangga karena tidak ada loyalitas pelanggan.

Untuk mengatasi hal ini maka Bogasari Flour Mills mengeluarkan produk dengan kemasan praktis $1 \mathrm{~kg}$. Dengan kemasan yang lebih kecil, harga bisa lebih terjangkau dan bisa menunjukkan bahwa kualitas terjaga karena di setiap kemasan tercantum tanggal kadaluwarsa. Dari sisi pemeliharaan, juga lebih mudah menjaga tingkat higienis, kebersihan maupun keputihannya, sehingga tidak perlu diayak sebagaimana dalam kemasan besar ketika akan digunakan untuk bahan baku kue atau roti. Namun yang lebih penting lagi dengan adanya kemasan kecil adalah pelanggan bisa lebih mengerti tentang brand name tepung terigu yang digunakan. Selain kemasan, diversifikasi produk juga dilakukan oleh Bogasari Flour Mills. Selain untuk lebih menyesuaikan kebutuhan pelanggan akan spesifikasi tepung terigu, diversifikasi produk seperti produk dengan kualitas rendah berharga murah sekaligus untuk menyaingi harga tepung terigu impor yang masuk ke Indonesia (Swasembada, 2001).

Sedangkan untuk lebih mendekatkan diri kepada pengguna tepung terigu khususnya UKM maka Bogasari Flour Mills menciptakan Bogasari Baking Training Center. Baking Training Center ini didedikasikan untuk seluruh lapisan masyarakat yang ingin mempelajari cara pengolahan tepung terigu, seperti cara pembuatan roti, kue, biskuit dan mie Bogasariflour. (2008b). Pada awalnya Bogasari Baking Training Center hanya didirikan di Jakarta (sejak 1981), dan di Surabaya (1996). Kemudian sejak perubahan perusahaan, terus dikembangkan di Bandung (1999) dan daerah-daerah lainnya. Sampai pada tahun 2005, sudah ada 32 sekolah Bogasari Baking Training Center di berbagai kota dengan alumni sekitar 20.000 (Indofood Sukses Makmur, 2005). Kiat lain Bogasari Flour Mills untuk menjaga kesetiaan sekaligus mengedukasi para mitranya adalah dengan menerbitkan Wacana Mitra, buletin yang terbit reguler, berisi informasi pasar, produk, maupun kiat/tip berbisnis bagi UKM bidang makanan. Dari survei 
Bogasari Flour Mills diantara mitra usahanya, hampir $99 \%$ dari mereka menjadikan media ini sebagai wadah tukar informasi dan pengalaman. Penerbitan buku-buku yang relevan dan bisa memperkaya wawasan para mitra juga dilakukan. Antara lain, buku Raja Makanan Berkibar dari jalanan yang berisi kumpulan kisah sukses para UKM bidang makanan (Swasembada, 2002).

Dari sisi suplai, setelah Bulog tidak lagi mensuplai bahan baku tepung terigu yaitu biji gandum, maka Bogasari Flour Mills mengimpor sendiri biji gandum. Impor gandum yang dilakukan Bogasari Flour Mills dilakukan sejak tahun awal tahun 1998 sebelum deregulasi tata niaga tepung terigu dan gandum berakhir pada akhir tahun 1998 . Impor biji gandum sebagian besar dilakukan dari negara-negara produsen gandum seperti Australia dan Canada melewati State Trading Entreprises (STEs) yaitu Australian Wheat Board dan Canadian Wheat Board (sekitar 80\%). Sedangkan sisanya dipasok dari negara-negara lain seperti Amerika Serikat, Argentina, dan sebagainya (Business Asia, 2000). Sedangkan dalam mengatasi masalah distribusi, sebelum dicabutnya peran Bulog dalam tata niaga gandum dan tepung terigu, distribusi dilakukan melalui Apegti (Asosiasi Penyalur Gula dan Terigu). Pada tahun 1999, saluran distribusi dirubah dengan mengurangi jumlah distributor dari yang sebelumnya sekitar 500 menjadi 49 yang terdiri dari rekanan distributor, depot Bogasari, maupun depot dengan joint operation. Jumlah outlet yang menjual produk Bogasari juga ditambah mencapai 20.000 terutama untuk menangani produk konsumen (consumer flour product) kemasan $1 \mathrm{~kg}$ (Indofood Sukses Makmur, 1999).

Upaya menerobos pasar mancanegara juga dirintis Bogasari Flour Mills tahun 1999, yaitu ke Singapura dengan volume 200 ton. Sejak itu, pasar ekspor diperluas ke negara-negara Asia lainnya. Ekspor ke
Timor Leste rata-rata 1.000 ton/bulan. Bogasari juga mengekspor terigu premix ke Jepang, mencapai 12 ribu ton pada tahun 2006. Selain tepung, Bogasari juga mengeskpor pasta (spaghetti dan makaroni) ke beberapa negara Asia dan Timur Tengah. Total ekspor sudah mencapai 3-4 ribu ton/bulan (2006). Selain terigu, Bogasari mengekspor pula produk sampingan, antara lain pelet (untuk pakan ternak, terutama unta) ke Timur Tengah sekitar 40 ribu ton/bulan. Untuk menjangkau pasar regional yang lebih luas, pada tahun 2001, Bogasari Flour Mills juga mendirikan fasilitas blending plant dibawah Bogasari Internasional di Singapura untuk memproduksi produkproduk adonan beku (frozen dough), tepung cepat saji (premix flour), dan berbagai produk lain berbasis tepung. Pabrik Bogasari International berdiri di atas lahan $4.510 \mathrm{~m} 2$ di kawasan industri Tuas Avenue. Dengan investasi US\$ 12 juta dolar dan kapasitas produksi 12 ton tepung spesial (premix) per jam (Swasembada, 2006).

Efektifitas strategi Bogasari Flour Mills dilihat dari sudut pangsa pasar (market share) bisa dilihat pada Tabel 10 (Swasembada, 2001; Kompas Cyber Media Online, 2003; Deperindag, 2003). Melonjaknya tepung terigu impor pada tahun 1999, berpengaruh dengan turunnya pangsa pasar Bogasari Flour Mills dari rata-rata sebelum krisis $87,9 \%$ menjadi $64,4 \%$. Namun setelah adanya perubahan perusahaan, penerapan strategi bersaing dan strategi marketing maka pangsa pasar Bogasari Flour Mills berlahan-lahan mulai naik lagi hingga mencapai $73,1 \%$ di tahun 2001 . Walaupun sempat turun pada tahun 1999, namun rata-rata pangsa pasar Bogasari Mills pada periode 2000-2004 mencapai 69,9\% (Gambar 3) dan masih menjadi pemimpin pasar (market leader) tepung terigu nasional (Swasembada, 2001; Kompas Cyber Media Online, 2003; Deperindag, 2003). 
Tabel 10: Market Share Tepung Terigu Indonesia Periode Tahun 1999-2004

\begin{tabular}{|c|c|c|c|c|c|c|c|c|c|c|c|c|}
\hline \multirow[t]{2}{*}{ Tahun } & \multicolumn{2}{|c|}{$\begin{array}{c}\text { PT Bogasari } \\
\text { Flour Mills } \\
\end{array}$} & \multicolumn{2}{|c|}{$\begin{array}{c}\text { PT Berdikari } \\
\text { Sari Utama } \\
\end{array}$} & \multicolumn{2}{|c|}{$\begin{array}{c}\text { PT Panganmas } \\
\text { Inti Persada }\end{array}$} & \multicolumn{2}{|c|}{$\begin{array}{c}\text { PT Sriboga } \\
\text { Ratu Raya }\end{array}$} & \multicolumn{2}{|c|}{ Import } & \multicolumn{2}{|c|}{ Total Suplai } \\
\hline & ton & $\%$ & & $\%$ & & $\%$ & ton & $\%$ & & $\%$ & & $\%$ \\
\hline 199 & 1709 & $64,4 \%$ & - & - & - & - & - & - & 370.487 & $14,0 \%$ & 4.205 & $100 \%$ \\
\hline 2000 & 3 & 67 & 256 & $8,4 \%$ & 149.4 & $4,9 \%$ & 10 & $4,6 \%$ & 45 & $\%$ & & 100 \\
\hline 2001 & 2 & $73,1 \%$ & 267 & $8,0 \%$ & 18 & $5,4 \%$ & 200 & $6,0 \%$ & & $\%$ & & $100 \%$ \\
\hline 2002 & 2.29 & $71,1 \%$ & 263 & $8,1 \%$ & 13 & $4,2 \%$ & 19 & $5,9 \%$ & 34 & $10,7 \%$ & 35 & $100 \%$ \\
\hline 2003 & 2.183 .704 & $68,6 \%$ & 330.465 & $10,4 \%$ & 146.018 & $4,6 \%$ & 185.842 & $5,8 \%$ & 336.765 & $10,6 \%$ & & $100 \%$ \\
\hline 2004 & 2.311 .497 & $69,3 \%$ & 402.246 & $12,1 \%$ & 134.271 & $4,0 \%$ & 160.007 & $4,8 \%$ & 326.087 & $9,8 \%$ & 3.334 .108 & $100 \%$ \\
\hline
\end{tabular}

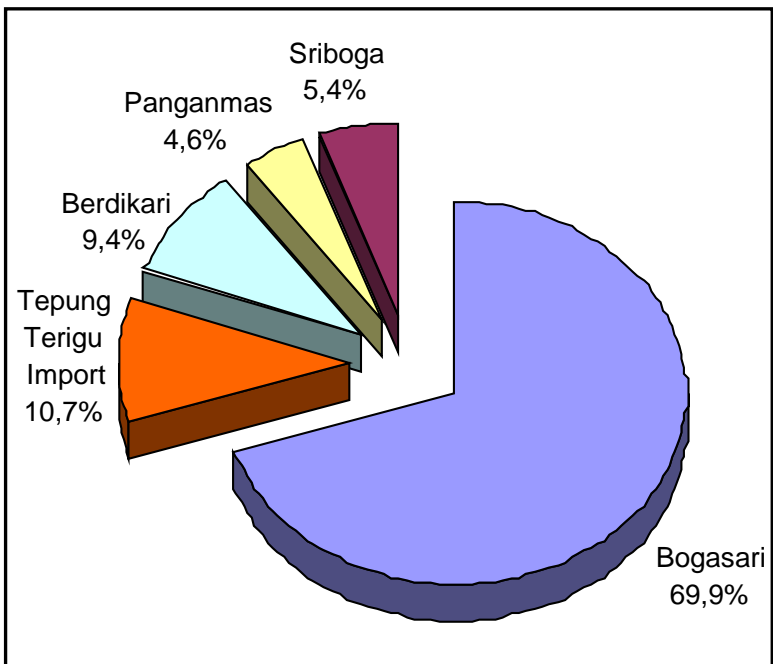

Gambar 3: Rata-Rata Pangsa Pasar Tepung Terigu Indonesia Periode Tahun 2000-2004

\section{Strategi Korporat (PT Indofood Sukses Makmur)}

Sebagai anak perusahaan, keberhasilan Bogasari Flour Mills, sebenarnya juga tidak lepas dari peran perusahaan induknya (parent company). Sejak didirikan pada tahun 1971, Bogasari Flour Mills dibawah kendali Salim Grup. Kemudian, pada tahun 1992, Bogasari Flour Mills diakuisisi oleh perusahaan yang masih dibawah naungan Salim Grup yaitu PT Indocement Tunggal Perkasa. Kejadian menarik terjadi pada tahun 1995, ketika Indofood Sukses Makmur mengakusisi Bogasari Flour Mills senilai Rp 1,4 trilyun dari PT Indo- cement Tunggal Perkasa (Indocement Tunggal Perkasa, 1995; Indofood Sukses Makmur, 2008) Ini merupakan strategi integrasi vertikal ke belakang (backward vertical integration) PT Indofood Sukses Makmur karena Bogasari Flour Mills melalui Bulog adalah pemasok tepung terigu terbesar yang merupakan bahan utama pembuatan mie instant. Dengan memiliki Bogasari Flour Mills, maka kebutuhan Indofood Sukses Makmur akan bahan baku mie

\footnotetext{
${ }^{6}$ Efektif 1 Juli 1995, PT Indocement Tunggal Perkasa menjual aktiva dan mengalihkan kewajiban serta usaha Bogasari Flour Mills kepada PT Indofood Sukses Makmur.
} 
instant menjadi lebih terjamin dibandingkan perusahaan pesaing lainnya. Hal ini juga berarti Indofood Sukses Makmur menciptakan barriers to entry bagi pesaing yang akan masuk ke dalam industri mie instant.

Pada tahun 1999, setelah deregulasi tataniaga tepung terigu dan gandum, maka Bogasari Flour Mills harus memasarkan produknya sendiri. Jaringan distribusi Indofood Sukses Makmur melalui anak perusahaannya khususnya Indomarco inilah yang digunakan oleh Bogasari Flour Mills untuk mendistribusikan produknya. Indomarco adalah distributor terbesar yang dimiliki oleh Indofood Sukses Makmur yang memiliki armada lebih dari 1400 kendaraan mobil box, 391 sepeda motor, serta fasilitas gudang yang berjumlah 126 yang tersebar di berbagai daerah, dengan jumlah karyawan sebanyak 4800 orang, termasuk 863 diantaranya merupakan tenaga penjualan. Sekitar $52 \%$ tenaga penjualan ini juga didukung oleh handled computer yaitu sistem komputerisasi untuk menerima pesanan dari tenaga penjualan di lapangan (Indofood Sukses Makmur, 2008).

Selain pemanfataan jaringan distribusi anak perusahaan Indofood Sukses Makmur, maka diversifikasi usaha Indoofood Sukses Makmur sebenarnya juga membantu penyerapan produksi tepung terigu Bogasari Flour Mills. Di Tabel 11 ditunjukkan rata-rata penyerapan produksi tepung terigu Bogasari Flour Mills oleh anak-anak perusahaan Indofood Sukses Makmur periode 2001-2007 adalah 18,2\% (Indofood Sukses Makmur Tbk and Subsidiaries,2008). Pada tahun 2006, penjualan antar segmen usaha (penjualan internal) Bogasari Flour Mills kepada anak-anak perusahan Indofood Sukses Makmur adalah Rp 1,7 trilyun atau sekitar $19 \%$ dari total penjualan Bogasari Flour Mills yang mencapai Rp 8.9 trilyun.

Tabel 11: Penjualan Internal dan Eksternal Bogasari Flour Mills Periode Tahun 2001-2007

\begin{tabular}{|c|c|c|c|c|c|c|}
\hline \multirow[t]{2}{*}{ Tahun } & \multicolumn{2}{|c|}{$\begin{array}{c}\text { Penjualan Internal } \\
\text { (Antar Segmen Usaha) }\end{array}$} & \multicolumn{2}{|c|}{ Penjualan Eksternal } & \multicolumn{2}{|l|}{ Total Penjualan } \\
\hline & $(\mathbf{R p})$ & $(\%)$ & (Rp) & $(\%)$ & $(\mathbf{R p})$ & $(\%)$ \\
\hline 2001 & Rp 936.530.152.498 & $17,6 \%$ & $\operatorname{Rp} 4.372 .897 .358 .927$ & $82,4 \%$ & Rp5.309.427.511.425 & $100,0 \%$ \\
\hline 2002 & Rp1.093.214.962.309 & $18,4 \%$ & $\operatorname{Rp} 4.833 .835 .619 .740$ & $81,6 \%$ & Rp5.927.050.582.049 & $100,0 \%$ \\
\hline 2003 & Rp1.047.526.981.309 & $17,2 \%$ & Rp 5.038.803.481.009 & $82,8 \%$ & Rp6.086.330.462.318 & $100,0 \%$ \\
\hline 2004 & Rp1.322.600.549.233 & $18,1 \%$ & Rp 5.986.220.240.483 & $81,9 \%$ & Rp7.308.820.789.716 & $100,0 \%$ \\
\hline 2005 & Rp1.463.309.000.000 & $18,5 \%$ & $\operatorname{Rp} 6.460 .089 .000 .000$ & $81,5 \%$ & Rp7.923.398.000.000 & $100,0 \%$ \\
\hline 2006 & Rp1.712.144.000.000 & $19,0 \%$ & Rp 7.285.279.000.000 & $81,0 \%$ & Rp8.997.423.000.000 & $100,0 \%$ \\
\hline 2007 & Rp2.147.691.000.000 & $18,5 \%$ & Rp 9.465.814.000.000 & $81,5 \%$ & Rp11.613.505.000.000 & $100,0 \%$ \\
\hline Rata-R & Rata & $18,2 \%$ & & $\mathbf{8 1 , 8 \%}$ & & $100,0 \%$ \\
\hline
\end{tabular}


Tinjauan Strategi Perusahaan di Negara Berkembang

Berangkat dari pemahaman bahwa lingkungan bisnis yang berubah-rubah dan peran pemerintah yang kuat dalam menentukan industri, terutama di negara berkembang, maka berimplikasi juga pada pembentukan strategi perusahaan. Sebaiknya, lingkungan bisnis tidak hanya dianggap sebagai faktor yang sudah tersedia (given) dalam pembentukan strategi perusahaan. Diperlukan juga sebuah pendekatan strategi yang lebih bersifat kontijensi (contingency) daripada sebuah strategi yang besifat linear (Ansoff and Sullivan, 1993) Selain itu implementasi strategi perusahaan juga bisa memberi pengaruh pada lingkungan bisnis yang ada disekitarnya, sehingga lingkungan bisnis dan strategi perusahaan saling memberi pengaruh (Uyterhoeven, Ackerman, and Rosenblum, 1972). Tidak cukup hanya beradaptasi dengan lingkungkan bisnisnya, sebuah perusahaan yang sukses adalah perusahaan yang mampu memberi pengaruh kepada lingkungan bisnisnya atau bahkan menciptakan lingkungan bisnisnya sendiri (Hamel and Prahalad, 2000).

Untuk memberi pengaruh pada lingkungan bisnis, maka diperlukan strategi. Namun strategi yang digunakan harus dibedakan antara market strategy dan nonmarket strategyseperti yang ditunjukkan pada Gambar 4 (Baron, 2000) Implementasi market strategy akan memberi pengaruh pada lingkungan nonmarket yang pada akhirnya akan direspon misalnya dengan

\footnotetext{
${ }^{7}$ Terjadi trend perubahan dalam strategi perusahaan yang sebelumnya hanya berdasarkan strategi fungsional, menjadi perusahaan yang mengacu pada lingkungan bisnis (environment driven firms).

${ }^{8}$ Dalam pengertian yang diberikan oleh Baron, market environment adalah lingkungan bisnis dimana perusahaan melakukan transaksi secara ekonomis. Sedangkan nonmarket environment adalah lingkungan bisnis yang meliputi sistem sosial, politik, serta berhubungan dengan perusahaan tanpa melalui transaksi ekonomi.
}

undang-undang, peraturan, bahkan perjanjian perdagangan internasional. Demikian juga pada aktivitas pada non-market pada akhirnya akan berpengaruh pada lingkungan market. Contoh pada kasus Bogasari Flour Mills adalah sebagai berikut: isu-isu tentang perlunya diversifikasi pangan oleh pemerintah (sisi nonmarket) akan berpengaruh pada pola makan masyarakat (sisi market). Maka perusahaan harus merespon dengan memberikan alternatif makanan selain beras, yaitu makanan dengan berbahan dasar gandum. Bisa juga sebaliknya, misalnya ketika perusahaan mengeluarkan penekanan tentang perlunya perlindungan pemerintah atas industri tepung terigu dengan meningkatkan bea masuk anti dumping tepung terigu impor (sisi nonmarket), maka akan berpengaruh pada peningkatan permintaan tepung terigu hasil produksi domestik (sisi market).

Lebih lanjut lagi, perlu dipetakan juga institusi atau aktor yang merupakan pemain pada masing-masing lingkungan bisnis agar implementasi strategi bisa berjalan efektif (Cummings and Doh, 2000). Ada empat institusi atau aktor yang harus diperhatikan oleh perusahaan dalam mengimplementasikan strategi pada lingkungan bisnis market yaitu: customers, suppliers, competitors dan complementors seperti yang disajikan pada Gambar 5 (Cummings and Doh, 2000). Contohnya, pasca krisis ekonomi 1997/1998, Bogasari Flour Mills menjaga hubungan dengan baik dengan pelanggannya yaitu Usaha Kecil dan Menengah (UKM), dan pihak supplier biji gandum (Australian Wheat Board, dan negara-negara eksportir gandum). Di sisi lain, Bogasari juga menciptakan halangan bagi pesaingnya dengan menciptakan saluran distribusi yang kuat bagi produknya, serta jaminan bahan baku bagi Indofood Sukses Makmur sebagai penghasil produk berbahan dasar gandum (complementors). 


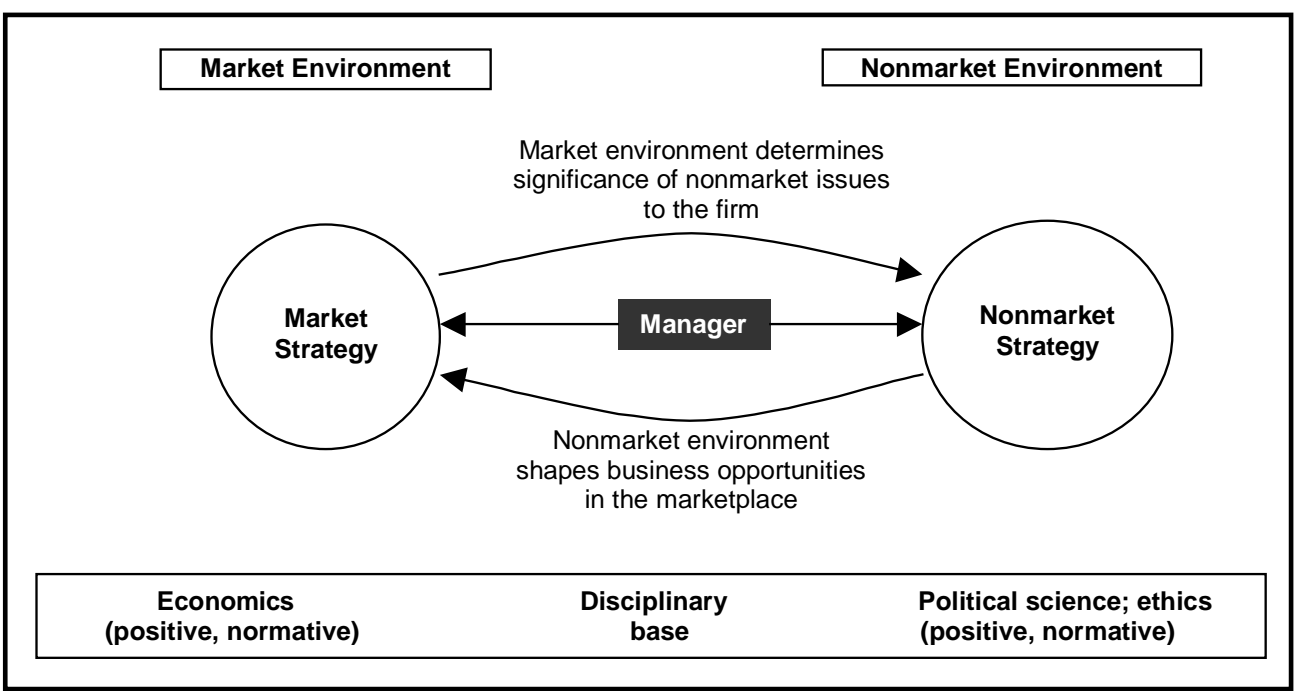

Gambar 4: The Environment of Business

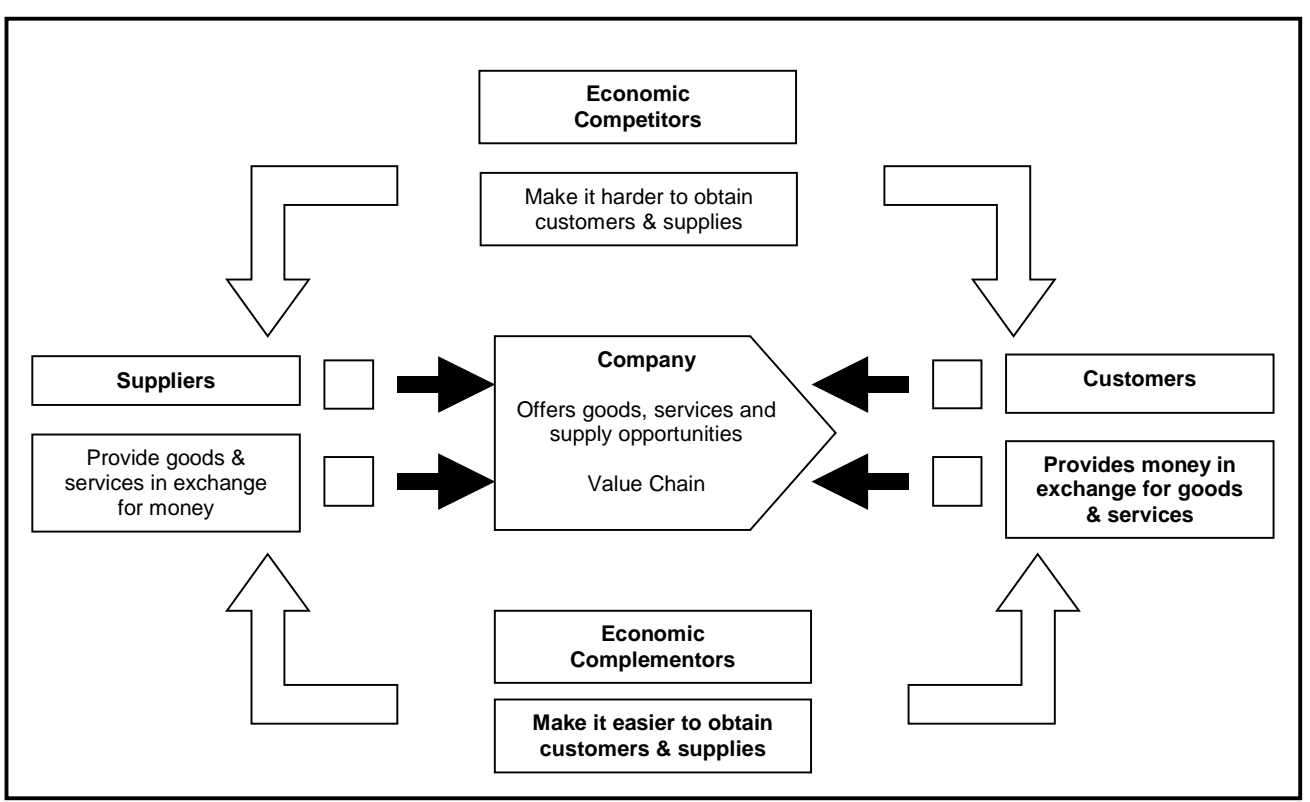

Gambar 5. Stakeholder Mapping and Valuation Economic Environment 


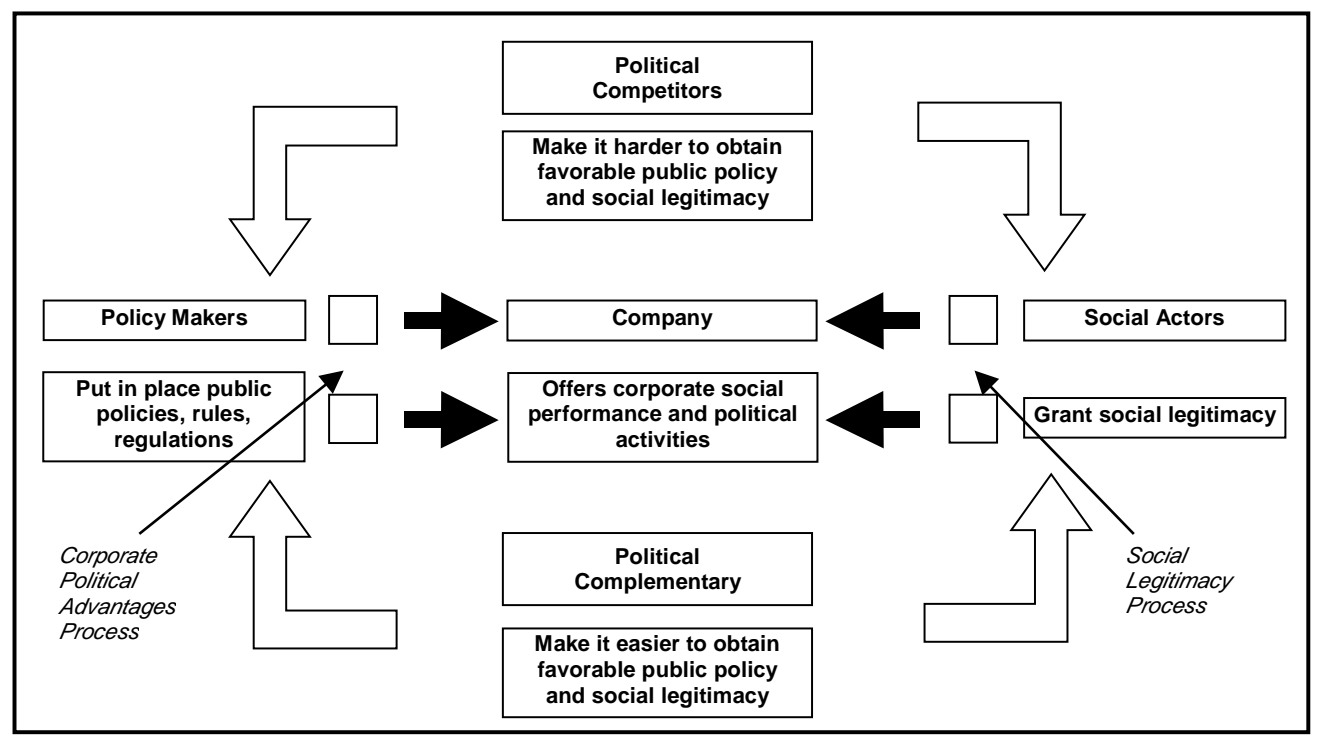

Gambar 6. Stakeholder Mapping and Valuation Political Environment

Sedangkan untuk lingkungan nonmarket, khususnya dalam lingkungan sosial politik bisa dilihat dalam Gambar 6 (Cummings and Doh, 2000). Perusahaan bisa mengarahkan strateginya kepada aktor atau institusi seperti pemerintah, kelompokkelompok kepentingan, dan politikus sehingga undang-undang, peraturan atau isu yang ada di masyarakat bisa menguntungkan perusahaan. Pembentukan Aptindo (Asosiasi Produsen Terigu Indonesia) misalnya mewakili kepentingan industri tepung terigu nasional untuk bernegosiasi dengan pemerintah tentang tarif bea masuk tepung terigu impor. Program Corporate Branding dengan mensponsori olah raga juga secara tidak langsung memberi pengaruh terhadap gambaran Bogasari Flour Mills kepada masyarakat tentang perusahaan yang peduli dengan pembangunan gizi bangsa.

\section{PENUTUP}

Pra krisis ekonomi 1997/1998, Bogasari Flour Mills mengimplementasikan strategi produksi dan operasi. Pemilihan strategi ini atas dasar pertimbangan bahwa supply dan demand dikuasai oleh Bulog. Sedangkan Bogasari Flour Mills hanyalah "maklun" menerima order dari Bulog. Padahal hanya ada dua produsen tepung terigu yaitu Bogasari Flour Mills dan Berdikari Sari Utama. Permintaan akan tepung terigu juga naik terus dari tahun ke tahun. Namun lingkungan bisnis pada sisi demand dan supply tidak berimplikasi secara langsung kepada perusahaan. Ini dikarenakan adanya proteksi dari pemerintah terhadap industri tepung terigu dan gandum. Secara struktur, yang jelas memberikan implikasi langsung terhadap perusahaan tentu saja Bulog dan pemerintah, karena keduanya inilah yang membuat sistem tata niaga tepung terigu dan gandum. Karena struktur (institusi dan lembaga) sangat menentukan terhadap industri dan perusahaan, maka nonmarket strategy sangat berperan disini. Kedekatan dengan pemerintah dan Bulog akan sangat menentukan keberhasilan perusahaan.

Menghadapi perubahan lingkungan bisnis, Bogasari Flour Mills juga turut berubah. Visi dan misi dibentuk dengan 
memberi porsi yang lebih pada pendekatan pasar (market oriented). Sedangkan strategi perusahaan yang sebelumnya fokus pada peningkatan kapasitas produksi juga dirubah menjadi strategi diferensiansi. Suplai bahan baku yang selama pra krisis ekonomi didapatkan dari Bulog, didatangkan sendiri oleh Bogasari Flour Mills terutama melalui Australian Wheat Board (AWB). Jalur distribusi juga dibenahi dengan memanfaatkan anak perusahaan Indofood Sukses Makmur yang bergerak dalam bidang distribusi (terutama Indomarco).

Untuk menghadapi serbuan tepung terigu impor yang dicurigai menerapkan terjadi dumping policy, aktivasi brand name segera dilakukan dengan melibatkan Usaha Kecil dan Menengah (UKM) yang menjadi target market Bogasari Flour Mills. Dari sisi produk, jika selama pra krisis ekonomi produk tepung terigu Bogasari Flour Mills hanya ada tiga macam (dengan ukuran sak $25 \mathrm{~kg}$ ), maka pra krisis ekonomi produk tepung terigu ditambah dengan berbagai macam kegunaan dan ukuran $(1 \mathrm{~kg}, 2 \mathrm{~kg}$ dan $25 \mathrm{~kg}$ ). Intinya, produk Bogasari Flour Mills dibikin untuk lebih melayani kebutuhan pasar. Tidak berhenti dalam mempertahankan pangsa pasar domestik saja, Bogasari Flour Mills juga mulai mengembangkan pangsa pasar eksport. Ini merupakan kesempatan bagi Bogasari Flour Mills dengan adanya liberalisasi perdagangan yang memudahkan perdagangan antar negara. Apalagi konsumsi produk berbahan dasar gandum cenderung meningkat di kawasan Asia.

Sedangkan nonmarket strategy, diimplementasikan dengan membentuk Aptindo bersama-sama produsen tepung terigu domestik lainnya untuk menekan pemerintah yang menerapkan bea masuk tepung terigu rendah. Peran corporate strategy menjadi catatan penting dalam kasus Bogasari Flour Mills. Serangkaian diversifikasi usaha Indofood Sukses Makmur tenyata berhasil menciptakan keunggulan bersaing anak-anak perusahaannya termasuk Bogasari Flour Mills.

\section{DAFTAR PUSTAKA}

Ansoff, H.I. and Sullivan, P.A. (1993). Optimizing Profitability in

Turbulent Environments: A Formula for Strategic Succes. Long Range Planning, 26 (5, Oktober), 11-23

Ariani, M. (2008). Trend Konsumsi Pangan Produk Gandum Indonesia. Pusat Penelitian dan Pengembangan Sosial Ekonomi Pertanian. Tersedia dialamat http://www.pustaka-deptan.go.id. Diakses pada tanggal 10 Mei 2008.

Austin, J.E. (1990). Managing in Developing Countries, Strategic Analysis and Operating Techniques. New York: The Free Press.

Badan Pusat Statistik (BPS). Berbagai laporan tahunan.

Baron, D.P. (2000). Business and Its Environment, $3^{\text {th }}$ Edition. New Jersey: Prentice Hall.

Bibeault, D.B. (1999). Corporate Turnaround. BeardBooks

Bogasariflour. (2008a). Industri Tepung Terigu Indonesia. Tersedia dialamat www.bogasariflour.com. Diakses pada tanggal 10 Mei 2008.

Bogasariflour. (2008b). Sejarah Perusahaan PT Bogasari Flour Mills. Tersedia dialamat www.bogasariflour.com. Diakses pada tanggal 7 Juli 2008.

Business Asia. (2000). Going Against the Grain - Wheat Impors in Indonesia. June. 
Cummings, J.L. and Doh, J.P. (2000). Identifying Who Matters: Mapping Key Players in Multiple Environments. California Management Review, 42 (2).

Dep. Perindustrian dan Perdagangan (Deperindag). (2003). Penjualan Terigu Selama 2003 Turun 1,44\%. Media Industri dan Perdagangan. Tersedia di alamat http://www.dprin.go.id. Diakses pada tanggal 28 Oktober 2008.

Eksekutif. (2002). Franciscus Welirang: Quota Usaha Kami Besar Bukan Karena Lampu Aladin. Edisi 279 (Oktober).

Gwie, K.K. (2006). Kebijakan Ekonomi Politik dan Hilangnya Nalar. Jakarta: Penerbit Buku Kompas.

Hamel, G. and Prahalad, C.K. (2000). Strategic Intent. in Broo, I. and Weatherston, J. (ed). The Business Environmnet; Challenges and Changes., Financial Times. $2^{\text {th }}$ Ed. Pp. 30. Prentice Hall.

Indocement Tunggal Perkasa. (1995), Annual Report 1992-1996.

Indocommercial. (1997). CAPRICORN Indonesia Consult Inc. No. 191. 11 Desember.

Indocommercial. (2001). Prospek Industri dan Pemasaran Tepung Terigu Di Indonesia. CAPRICORN Indonesia Consult Inc. No. 280. 26 Agustus.

Indocommercial. (2005). CAPRICORN Indonesia Consult Inc. No. 363. 16 November.

Indofood Sukses Makmur Tbk and Subsidiaries. (1998). Financial Statements. 1992-1997.
Indofood Sukses Makmur Tbk and Subsidiaries. (2008). Financial Statements. 2001-2007.

Indofood Sukses Makmur. (1999). Annual Report.

Indofood Sukses Makmur. (2005). Annual Report, 19 Desember

Indofood Sukses Makmur. (2008). Annual Report 1995-2007.

Indonesia and IMF. (1997). Letter Of Intent, 31 Oktober. Tersedia di alamat http://www.imf.org. Diakses pada tanggal 10 Mei 2008.

Keputusan Menteri Perdagangan Republik Indonesia. (1995). Barang-Barang yang Diatur Tata Niaga Impor. No. 89.

Keputusan Presiden (Keppres). (1991). Daftar Bidang Usaha yang Tertutup Bagi Penanaman Modal. No. 23.

Keputusan Presiden (Keppres). (1992). Penetapan industri tepung terigu dalam Daftar Negatif Investasi (DNI). No. 32.

Kompas Cyber Media Online. (2003). Produsen Terigu Sesalkan Sikap Menkeu soal Bea Masuk Terigu. 24 Januari, Tersedia di alamat http://www.kompas.com. Diakses pada tanggal 1 November 2008.

Kompas. (1992). Badan Urusan Logistik dan Anda. 10 Mei.

Kompas. (1998). Fenomena Monopoli Dalam Kancah Bisnis Indonesia. 14 Desember.

Kontan Online. (2006). Perang Sengit di Terigu Menguping Kabar Pabrik Terigu, 10 (33), 22 Mei Tersedia di alamat www.kontan-online.com. 
Diakses pada tanggal 10 Oktober 2008.

Media Indonesia Online. (2008). Kilas Balik Tataniaga, Sampai Kapan?. Jumat, 14 Desember 2007. Tersedia di alamat http://web.bisnis.com. Diakses pada tanggal 10 Mei 2008.

Muhammad, S. (2004). Manajemen Strategik, Konsep dan Kasus. Edisi Ketiga. Yogyakarta: Unit Penerbitan dan Percetakan Akademi Manajemen Perusahaan YKPN.

Pusat Data Business Indonesia. (1994). Indonesian Food Industry. $2^{\text {th }}$ edition.

Robinson, R. (1986). Indonesia: The Rise of Capital, A publication ot the Asian Studies Association of Australia. Allen \& Unwin.

Sinar Harapan (2002). Bea Masuk Anti Dumping Terigu Agar Diterapkan. 16 Januari.

Swa. (2007). Mereka yang Menari di Atas Gelombang Perubahan. 1 Februari.
Swasembada. (2000). Jurus Berkelit Bogasari dari Gempuran Pemain Baru. No. 01.17 Januari-26 Januari.

Swasembada. (2001). Membrandingkan Terigu, Ayo Saja!. No. 22. 30 Oktober-7 November.

Swasembada. (2002). Kiat Bogasari, Mengikat Para Mitra Usaha. No. 07. 4 April-17 April.

Swasembada. (2006). Branding di Pasar Internasional. 05 Oktober.

Thompson Jr, A.A. and Strickland, A.J. (2003). Strategic Management, Concepts and Cases. $13^{\text {th }}$ edition. McGraw-Hill.

Trust. (2008). Cendera Mata yang Terus Bersinar. Tersedia dialamat http://www.majalahtrust.com, Diakses pada tanggal 10 Mei 2008.

Uyterhoeven, H.E.R., Ackerman, R.W. and Rosenblum, J.W. (1972). Strategy and Organization, Text and Cases in General Management. Richard D. Irwin, Inc. 